\title{
Factors Influencing Employee Quality of Work Life in Andhra Pragathi Grameena Bank with Special Reference to Kadapa District
}

\author{
Kothapalle Inthiyaz, T. Narayana Reddy, P. Subramanyachary
}

\begin{abstract}
The term Quality of work Life (QWL) aims at self-propelled entire structure climate by humanizing work, individualizing the organization and self-propelled the structural and group action system. It seeks to create culture of labor commitment at intervals the organization which might guarantee higher productivity for the companyand greater job satisfaction for the employees, it's as vital to acknowledge that there are sure issues that everyone folks have in common, a minimum of to a point. Quality of labor Life policies are more and turning into a part of the business ways and focus is on the potential of those policies to influence employee's quality of operating life and more significantly to assist them maintain work-life balance with equal attention on performance and commitment at work. One in all the foremost vital determinants of Quality of work Life $(Q W L)$ is that the career growth opportunities as supported by varied researches drained past
\end{abstract}

Keywords: Career growth, Job satisfaction, Performance, Quality of Work Life, Level of job Satisfaction, Superior Relationship, Compensation

\section{INTRODUCTION}

The term Quality of Work Life gained importance within the late sixties as a mode of concern regarding effects of profession/employment on health and general well-being and ways that to absolutely influence the standard of a person's work expertise. Up till the mid-1970s, employers concern was on work style and dealing conditions improvement. However, within the next decade of eighties, the conception of QWL enclosed alternative aspects that have an effect on employee's satisfaction and yield and these aspects are, pay \& reward, work setting, worker involvement, privileges and appreciate desires (Cummings and Worley, 2005).

According to ASTD, QWL is a process of business organization which enables its employees at ever levels to take part in actively and efficiently in determining the work environment, different modes and outcome. Richard $\mathbf{E}$ Walton, stated that a concept of QWL propose 8 abstract

Revised Manuscript Received on July 22, 2019.

K. Inthiyaz, Research Scholar, Department of Management Sciences, JNTUA, Anantapuramu, India. Email: yaaz2012@gmail.com

T. Narayana Reddy, Associate Professor, Department of Management Sciences, JNTUA, Anantapuramu, India. Email: tnreddyjntua@gmail.com

P. Subramanyachary, Professor, Department of Management Sciences, Siddhartha Institute of Engineering and Technology, Puttur, India. Email: palakonda001@gmail.com

categories viz. adequate and fair compensation, safe and healthy working conditions, opportunity to use and develop human capacities, future opportunity for continued growth and security, social integration in the work place, social relevance of work, balanced role of work in the total life space and Constitutionalism in the Work Organization etc. it is rare to find work-life situations that satisfy all eight criteria.

QWL indicates the entire hierarchical data sources which go for member of staff accomplishment\& improving trustworthy adequacy. QWL is a process by which an employees association reacts to employee wants for making instruments to modify them to share entirely in selecting the selection that organization their lives at work place. The term permits to the idealness or un-positivity of a highly professional scenario for persons. QWL programs are another manner by those associations understands their duty to make professionals and dealing atmosphere that are superb for people even as for monetary accuracy of the association. The parts during a common QWL program incorporates fair and open interchanges, equitable payment frameworks, a worry for representative skilled stability and fulfilling vocations and investment in basic leadership. Quality of work life endeavors hub around occupation improvement. all the same rising the work structure, QWL programs for the foremost half emphasize development of ambassador aptitudes and cut back of word connected stress and therefore the progression of additional co- employees the chief relations.

1. QWL is a far thinking, organization wide scheme assign to pick up leadership fulfilment, reinforcing work place culture and helping human resources would do well to attain global standards and progress.

2. Unhappiness with QWL is a subject, which influences practically all unskilled workers pay less attention on position or condition. Plentiful chiefs strive to mining distress in each authoritative measurement, including their individual. This is a not able to be predictable problem, be that as it may, in glow of the reality that it is solid to seclude and differentiate all of distinctiveness, which influence the QWL.

3. Sometimes curtailed QWL, nature of work life is snappy appearance that includes an enormous agreement, since it speak briefly to the object a company does that adds to the lives of representatives. Those "objects" are a mix 
together of recompense convey and inferred unmistakable and imaginary that makes some place a decent work atmosphere. Suggested in the area of QWL is the idea that to be a polite boss, a business or establishment must perceive that representatives have lives when work. That acknowledgment, thus, makes trust and devotion among workers, one and all benefits and the globe is a greater spot. Quality of work life has also been viewed in a variety of ways including:

- As a progress;

- As a set of organizational intervention and

- A type of work life by human resources

4. QWL is a zestful multidimensional build that presently includes such concepts as employee security, pay systems, training and career development opportunities, and chipping in in decision making.

5. As such QWL has been defined as the place of work blue print, functioning and location that nurture and keep up employee satisfaction with an aim to improving working circumstances for human resources and organizational fruitfulness for employers. The basic purpose is to develop jobs and working circumstances that are tremendous for people as well as for the monetary health of the organization. It seeks to spend the higher skills of human resources and to afford a surroundings that encourages improving their skills.

Vital things to pick up the work life of human resources in the organization

$$
\begin{aligned}
& \text { - Q - Quest of superiority } \\
& \text { - U - Understanding } \\
& \text { - A - Action } \\
& \text { - L - Leadership } \\
& \text { - I - Involvement of the public } \\
& \text { - T - Team Sprit }
\end{aligned}
$$

Y - Yardstick to determine progress

\section{REVIEW OF LITERATURE}

R. Geetha et al., (2016) deliberated in research paper after the literature review on QWL. It is understandable that an organization cannot obtain competent and valuable results from the human resources without QWL. Quality is important for employees as well as for the organizations to attain the overall escalation and revenue in the market. The journalism also reveals the giving of the 9 chief components of Quality of Work Life which are absolutely associated with the employee satisfaction and employees' estimation on QWL in different sectors. Given high pay, the human resources are cheerful to increase their knowledge, ability and skills and work for the steps forward of the organization and forthwith their own promotion.

Giang Thuy Phan, Trung Quang Vo (2016) considered in his piece of writing that Quality of Work Life is covered additionally in arrange to pick up quality and output of functioning in organizations. Moreover, the research study reveals some factors affecting the Quality Work Life such as work satisfaction, working environment, Adequate and fair compensation, employee's relations, employer's personnel

relations and support to be better manager change and transportation facilities. They are so main factors to identify and admission the advantages and disadvantages of environmental workplace to get the correct answer addressing limiting factors and pick up Quality of Work life.

S. Khodadadi et al. (2014) investigated the Quality of Work life dimensions collision on the workers' action completion. In this inspection independent factors were perpetual safety giving, salary and advantages compensation preparations, improvement and career development opportunity, and employment flexibly, work execution as the dependent factors. One hundred fourteen representatives chose randomly for this study and 2 surveys of "QWL" and "job engagement" was utilized for information gathering and Data analyzed by using SPSS and LISREL programming. The aftereffects of the examination verified that the salary and advantages' approaches have a of note and productive result on Shuhstar's Shohola Hospital representatives' bustle accomplishment

H. Mohammadia \& M. A. Shahrabib (2013) conducted a research on relationship between QWL and job satisfaction, it is an experimental inquiry. Opinion poll in Likert scales format and spread among eight six permanent employees of 2 Government agencies in Iran, Supreme Audit Court and Interior Ministry and t-test used to check up the hypothesis. The outcome indicates that dissimilar working apparatus have significantly prejudiced on job satisfaction.

\section{Statement of the Problem}

For the present investigation, the term Quality of Work Life represents the amenities and facilities which are expected by the employees. The "working life balance" comprises of numerous components, for example, salary, Promotion, Opportunity for Continued Growth and Security, Benefits, Contingent Rewards, Safe and Healthy Working Conditions, Operating Procedures, subordinate and Supervision, quality Work, Social Integration in the Work Organization, Constitutionalism in Work Organization, Work and Total Life Space, and Social Relevance of Working Life; every one of which assumes its job in assessing working life Maintaining authoritative well-being just as the worker's fulfillment all the time is one of key factor for making hierarchical progress and furthermore for the hierarchical maintainability. On the off chance that personal satisfaction at work could be improved, it would profit and reward the individual representative and the association, its workers and society all in all. As businesses attempt to address worker turnover and employment fulfillment issues, they should initially figure out what the issues are. As more associations understand that a glad worker is a profitable representative, they have begun to search for approaches to improve the workplace. Many have executed different work-life projects to support representatives, including substitute work courses of action. It can't be characterized or suggested in a couple of terms or sentences as it is the assembly of different elements like nature of the activity, idea of the individual worker and manager, workplace, social condition, work offices, destinations and objectives of the association, capability, 
experience and dreams of the human components integrated so on and so forth.

\section{Objectives of the study}

1. To identify the key factors of Quality of Work Life of employees.

2. To measure the impact of major factors on quality of work life.

\section{Hypothesis of the study}

Ho: There is no significant relationship between key factors and QWL.

$\mathbf{H}_{1}$ : There is significant relationship between key factors and QWL.

\section{RESEARCH METHODOLOGY}

Research is an intensive study in a particular field to achieve at an improved conclusion of a problem. Research Methodology is a systematic way of solving the problem. The methodologies followed for this study are as follows.

\section{Research Design}

The research design is the basic framework or a plan for a study that guides the collection of data and analysis of data. Employees satisfaction and opinion about this study is used Descriptive Research Design in nature. The main purpose of descriptive research is description of state of affairs, as it exists at present. The information is collected from the employees in Andhra Pragathi Grameena Bank and analyzed with the help of different statistical tools, for describing the relationship between various variables, pertaining the job satisfaction and quality of work life. Moreover, cross table analysis has been done for processing the data and information is derived to attain the objectives of the study.

\section{Method of Data Collection}

Among the various methods, which can be used to collect the primary data, the researcher has adopted two methods which are Structural Questionnaire method. The researcher has prepared structured questionnaires, which contained predominantly multiple choice questions. The respondent's opinions are gathered with regard to the problem with the help of the questionnaires.

\section{Sampling Design}

A sample is a smaller representation of a larger whole. When some of the elements are selected with the intention of finding out something about the population from which they are taken, that group of elements is referred as a sample, and the process of selection is called Sampling.

\section{Sampling Unit}

The respondents of the study are part of population of employees of Andhra Pragathi Grameena Bank, Kadapa district. Each employee is considered to be the sampling unit.

\section{Sample Size}

Andhra Pragathi Grameena Bank employee's strength is identified the entire universe; meanwhile the sampling size is confined only for 150 employees for among various cater of position in their jobs. Convenient sampling is adopted to get insight about the study.

\section{Statistical Tools}

The collected data is consolidated, tabulated and analyzed by using statistical tools like KMO \& Bartlett's Test of Sphericity, Factor analysis, Multiple Regression and ANOVA test.

\section{Period of the Study}

The study was conducted for a period of 3 months from June to August 2018 and collected data through online mode

\section{DATA ANALYSIS \& RESULTS}

The Data analyzing using tools is SPSS20.0 version

\section{Gender}

From the above table it can be inferred that, out of 150 respondents, $63.3 \%$ of the respondents were male and the remaining $36.7 \%$ were female respondents. It is observed that the majority of respondents are male.

Age

From the above table it very well may be surmised that, out of 150 respondents, $54.0 \%$ of the respondents have a place with age gathering of $31-40$ years and $18.0 \%$ of the respondents have a place with age gathering of 20-30, $16.0 \%$ of the respondents have a place with age gathering of 41-50 years. The staying $12.0 \%$. Of the respondents are over the age of 50 years. This demonstrates dominant part of the respondents is youths and adults.

\section{Marital Status}

The above table it can be inferred that, out of 150 respondents, out of which $40.7 \%$ were unmarried and the remaining 59.3\% are "Married". This shows the more participation from married respondents.

\section{Occupation}

The above table it can be inferred that out of 150 respondents, out of which $47.3 \%$ of the total respondents were employees, $30.7 \%$ were Bank P. O, $13.3 \%$ were others $8.7 \%$ were Managers.

\section{Qualification}

The above table is can be inferred that, out of 150 respondents, out of which $50.7 \%$ respondents belongs to Postgraduates, $28.0 \%$ respondents belongs to Other categories, $21.3 \%$ respondents belonged Under Graduates Hence, this study comprises of majority of the respondents of Postgraduates.

\section{Published By:}


Factors Influencing Employee Quality of Work Life In Andhra Pragathi Grameena Bank With Special Reference To Kadapa District

Income

The above table is can be inferred that, out of 259 respondents, $27.4 \%$ of the respondents reported to have income range of Rs. 75001-1 Lakh, 24.0\% reported their income range should be Rs. 25000-50000. 23.3\% reported their income range should be Rs. 50001-75000 and Rs.
25000 below. $4.7 \%$ reported their income range is Rs. 1 Lakh above.

Table 1: Description of Demographic Data

\begin{tabular}{|c|c|c|c|}
\hline \multicolumn{2}{|c|}{ Demographic Variable } & Frequency & Percentage \\
\hline \multirow{3}{*}{ Gender } & Male & 95 & 63.3 \\
\hline & Female & 55 & 36.7 \\
\hline & Total & 150 & 100 \\
\hline \multirow{5}{*}{ Age } & $20-30$ & 27 & 18.0 \\
\hline & $31-40$ & 81 & 54.0 \\
\hline & $41-50$ & 24 & 16.0 \\
\hline & $>50$ & 18 & 12.0 \\
\hline & Total & 150 & 100.0 \\
\hline \multirow{3}{*}{ Marital Status } & Married & 89 & 59.3 \\
\hline & Unmarried & 61 & 40.7 \\
\hline & Total & 150 & 100.0 \\
\hline \multirow{5}{*}{ Occupation } & Managers & 13 & 8.7 \\
\hline & P. O & 46 & 30.7 \\
\hline & Employees & 71 & 47.3 \\
\hline & Others & 20 & 13.3 \\
\hline & Total & 150 & 100.0 \\
\hline \multirow{4}{*}{ Qualification } & UG & 32 & 21.3 \\
\hline & PG & 76 & 50.7 \\
\hline & Others & 42 & 28.0 \\
\hline & Total & 150 & 100.0 \\
\hline \multirow{6}{*}{ Income } & $<25000$ & 35 & 23.3 \\
\hline & $25000-50000$ & 36 & 24.0 \\
\hline & $50001-75000$ & 35 & 23.3 \\
\hline & 75001-1 Lakh & 37 & 24.7 \\
\hline & > Lakh & 7 & 4.7 \\
\hline & Total & 150 & 100.0 \\
\hline
\end{tabular}

Table 2: KMO \& Bartlett's Test of Sphericity

\begin{tabular}{|l|l|c|}
\hline Kaiser-Meyer-Olkin Measure of Sampling Adequacy. & .769 \\
\hline \multirow{3}{*}{ Bartlett's Test of Sphericity } & Approx. Chi-Square & 608.893 \\
\cline { 2 - 3 } & Df & 45 \\
\cline { 2 - 3 } & Significance & .000 \\
\hline
\end{tabular}

Data set was then subjected to another round of Principal Component Analysis and Varimax rotation. Communalities for all nineteen variables were higher than 0.5 (Annexure I) indicating it to be an optimum solution. Final solution explained $\mathbf{6 7 . 1 1 8} \%$ of total variance associated with the problem (Annexure II). Factor output comprised of three factors based on ten variables (Annexure III). Relevant factor loadings for each variable indicated that all the variables were adequately explained by derived factors. Factor output comprised of three factors representing specific forces quality of work life in banking industry in Anantapur district, Andhra Pradesh. These are presented in the table given below. 
Table 3: Name of the Factors

\begin{tabular}{|c|c|c|c|}
\hline \multirow[b]{2}{*}{ Statements } & \multicolumn{3}{|c|}{ Component } \\
\hline & Compensation & Superior Relationship & Level of job Satisfaction \\
\hline $\begin{array}{l}\text { Employee's opinion regarding the } \\
\text { Quality of Work Life }\end{array}$ & .830 & & \\
\hline Employees' satisfaction with current Job & .825 & & \\
\hline $\begin{array}{l}\text { Employees' opinion regarding the } \\
\text { Cordial Relationship between the } \\
\text { employees and superiors }\end{array}$ & 698 & & \\
\hline $\begin{array}{l}\text { Employees' opinion regarding the safety } \\
\text { and healthy Working conditions }\end{array}$ & .696 & & \\
\hline $\begin{array}{llll}\begin{array}{l}\text { Employees' satisfaction with Salary } \\
\text { package }\end{array} & & \\
\end{array}$ & .618 & & \\
\hline $\begin{array}{l}\text { Employees' opinion regarding the job } \\
\text { security in the organization }\end{array}$ & & .880 & \\
\hline $\begin{array}{l}\text { Employees' satisfaction with the } \\
\text { grievance redresses }\end{array}$ & & .850 & \\
\hline $\begin{array}{l}\text { Employees' opinion regarding the } \\
\text { Performance Appraisal methods }\end{array}$ & & .838 & \\
\hline $\begin{array}{l}\text { Main satisfactions in employee life come } \\
\text { from their work. }\end{array}$ & & & .898 \\
\hline Levels of satisfaction & & & .614 \\
\hline
\end{tabular}

Table 4: Regression Model-Summary

\begin{tabular}{|c|c|c|c|c|c|c|c|c|c|}
\hline \multirow[b]{2}{*}{ Model } & \multirow[b]{2}{*}{$\mathbf{R}$} & \multirow[b]{2}{*}{$\begin{array}{c}\text { R } \\
\text { Square }\end{array}$} & \multirow[b]{2}{*}{$\begin{array}{l}\text { Adjusted R } \\
\text { Square }\end{array}$} & \multirow{2}{*}{$\begin{array}{c}\text { Standard } \\
\text { Error of the } \\
\text { estimates }\end{array}$} & \multicolumn{5}{|c|}{ Change Statistics } \\
\hline & & & & & $\begin{array}{c}\text { R } \\
\text { Square } \\
\text { change }\end{array}$ & F Change & df1 & df2 & Sig F Change \\
\hline 1 & $.479^{\mathrm{a}}$ & .229 & .213 & .728 & .229 & 14.463 & 3 & 146 & .000 \\
\hline
\end{tabular}

Source: Primary data through questionnaire.

a. Predictors: (Constant), Level of job Satisfaction, Superior Relationship, Compensation

b. Dependent Variable: Quality of Work Life

\section{Inference}

Model summary (Table) shows the value of $\mathrm{R}$ as 0.696 , $\mathrm{R}$ Square as 0.484 and adjusted $\mathrm{R}$ square value as 0.474 which indicates that this regression model explains about \% of variation of dependent variable (Quality of work life) due to independent variable (Compensations, Superior Relationship \& Level of job Satisfaction).

Table 5: ANOVA

\begin{tabular}{|c|r|r|r|r|}
\hline Model & Sum of Squares & Df & Mean square & F \\
\hline 1 Regression & 22.978 & 3 & 7.659 & \\
\hline Residual & 77.316 & 146 & .530 & 14.463 \\
\hline Total & 100.293 & 149 & & $.000^{\mathrm{b}}$ \\
\hline
\end{tabular}


Source: Primary data through questionnaire.

a. Dependent Variable: Quality of Work Life

b. Predictors: (Constant), Compensation, Superior Relationship \& Level of job Satisfaction.

\section{Inference}

The ANOVA (Table) reveals that the F statistics of the regression model is statically significant at 0.05 levels implying the goodness of fit of the regression equation. (Model is statistically significant).

Table 6: Coefficient

\begin{tabular}{|c|c|c|c|c|c|}
\hline \multirow[t]{2}{*}{ Model } & \multicolumn{2}{|c|}{ Unstandardized Coefficients } & \multirow{2}{*}{$\begin{array}{c}\begin{array}{c}\text { Standardized } \\
\text { Coefficients }\end{array} \\
\text { Beta }\end{array}$} & \multirow[t]{2}{*}{$\mathbf{T}$} & \multirow[t]{2}{*}{ Sig. } \\
\hline & $\mathbf{B}$ & Std. Error & & & \\
\hline Constant & 2.640 & .289 & & 9.123 & .000 \\
\hline Compensation & .192 & .060 & .258 & 3.191 & .002 \\
\hline $\begin{array}{l}\text { Superior } \\
\text { Relationship }\end{array}$ & -.179 & .090 & -.155 & -1.994 & .048 \\
\hline $\begin{array}{l}\text { Level of job } \\
\text { Satisfaction }\end{array}$ & .167 & .053 & .240 & 3.127 & .002 \\
\hline
\end{tabular}

a. Dependent Variable: Quality of Work Life.

Source: Primary data through questionnaire.

\section{Inference}

Table represents standardized regression coefficients which show the strength of impact and its positive/ negative direction. It comprises ' $t$ ' and significant values to validate the hypothesis framed to measure the significant impact of dimensions of key factors on quality of work life.

\section{Suggestions}

- Adequate training and development programs should be accommodated to the employees for an effective increase in the performance and attitude levels.

- More recreational facilities and welfare measures should be provided by the company to reduce work stress and to enhance the satisfaction of their working environment.

- Top level executives and immediate supervisors should try to create healthy relations with their subordinates to motivate the performance of the employees and workmen.

- The safety measures in the company should be improved in order to improve the functioning of the quality circles.

- The Performance Appraisal is to be conduct frequently and analyze the employee's recital which should lead to satisfy their monetary and non-monetary terms.

- The company must adopt a regular system to assess the graveness and problem of the employees

\section{CONCLUSION}

The study found that there is a high level of satisfaction among the employees regarding the Quality of Work life. The factors determining the satisfaction with the quality of work life in the organization were "Adequate Income \& Fair Compensation, Safe \& healthy working conditions, Opportunities to use \& develop human capacity, Opportunity for career growth, Social integration in the work force, Constitutionalism in work organization, Eminence of Work Life and Social relevance of work, Cordial relationship with employees and superiors, and remedy for the grievance and performance appraisal. All these factors are positively correlated with the quality of work life in Andhra Pragathi Grameena Bank of YSR district. Adequate training and development programs should be provided to the employees for an effective increase in the performance and attitude levels 


\section{REFERENCES}

1. Allenspach, H., Flexible Working Hours, Geneva, International Labour Office, 1975, pp-64.

2. Aswathappa. K, Human Resource and Personnel Management, second edition (2002), Tata Mc Graw Hill Publishing Company, New Delhi, pp $(390,391,523)$.

3. Bhatia, S. K. and G. K. Valecha, A Review of Research Findings on Absenteeism, Indian Journal of Industrial Relations, October, 1981, Vol. 17(2), pp 1234 .

4. Biswanath Ghosh, Human Resource Development and Management (2000), Vikas Publishing House Pvt. Ltd., Page (26 -27).

5. Dolan, L.S, Garcia, S. Cabezas, C. and Tzafrir, S.S., Predictors of "Quality of Work" and "Poor Health" Among Primary Health-Care Personnel in Catalonia. International Journal of Health Care Quality Assurance. 21(2); Pp. 203-218, 2008.

6. Inthiyaz, K. (2017). A Study on Quality of Worklife of Employees in AndhraPragathi Grameena Bank with Special Referennce to YSR District. International

7. Feuer, D., Quality of work life: a cure for all ills? Training: The Magazine of Human Resources Development, 26: 65-66, 1989.

8. Gilgeous, V., (1998), "Manufacturing managers: their quality of working life", Integrated Manufacturing System, Vol. 9, No. 3, pp.173-181.

9. Goode, D. A. 'Quality of Life, Quality of Work Life' in W. E. Kiernan and R. L. Schalock (eds.), Economics, Industry and Disability: A Look Ahead (Paul H. Brookes, Baltimore), pp.337-349, 1989.

10. Hackman, J.R., \& Oldham, G.R., (1980), "Work redesign", Redings, M.A: Addison-Wesley.

11. Hair, J. F; Anderson, R. E and Tatham, R.L. 1999.Multivariate Data Analysis. 2nd edition. Macmillan publishing company, New York. PP 111-114.

12. Hart, P.M., Teacher Quality of Work Life: Integrating Work Experiences, Psychological Distress psychological distress, Occupational Organizational Psychology 67:109-132, 1994.

13. Herzberg, F., Mausner, B., and Snyderman, B. (1959), "The Motivation to Work" (2nd ed.) New York: John Wiley.

14. Hian, C.C., and Einstein, W.O., (1990), "Quality of Work Life (QWL): What can unions do? S.A.M. Advanced Management Journal, Vol. 55, No. 2, p. 17-22.

15. Karasek, R.A. "Control in the Workplace and its Health-Related Aspects", in Sauter.

16. Kohl, M. L and Schooler, C., 'Job conditions and personality: A Longitudinal Running in the direction of the long axis of the body or any of its parts. Assessment of Reciprocal Effects', American Journal of Sociology 87: 1257-1286, 1982.

17. Koonmee, K. A. Singhapakdi, B. Virakul and D. J. Lee, Ethics institutionalization, Quality of Work Life and employee job related outcomes: A survey of human resource managers in Thailand, Journal of Business Research, 2010, 1-7, 20-26.

18. Lau, R.S.M and May, B.E., (1998), "A win-win paradigm for Quality of Work Life and business performance", Human Resource Development Quarterly, fall 1998, Vol 9, No. 3.

19. Lee, J.D., Singhapakdi, A. and Sirgy, J.A., Further Validation of a Need-based Quality-of-work-life (QWL) Measure: Evidence from Marketing Practitioners. Applied Research in Quality of Life.2 (4), 273-287, 2007.

20. Robert Half Management Resources; Investment Weekly News. Atlanta: Jan 8, 2011. pg. 675.

21. Royuela, V., Tamayo, J and Surinach, J. The Institutional vs. the Academic Definition of the Quality of Work Life. What is the Focus of the European Commission? Research Institute of Applied Economics 2007.

22. S.L., Hurrell, J.J., Cooper, C.L. (Eds), Job Control and Worker Health, Wiley, New York, NY, pp.129-59, 1989.

23. Sinha P, Sayeed OB. Measuring Quality of Working Life: Development of an Inventory. Indian Journal of Social Work.41; 219-226, 1980.

24. Sirgy, J.M, Efraty, D, Siegel, $P$ and Lee, J.D A New Measure of Quality of Work Life (QWL) based on need satisfaction and spillover Social Indicators Research 55:241-302, 2001.

25. Inthiyaz, K. (2017). Impact of employee skill development on organizational performance in banking industries with special reference to YSR district. International Journal of Engineering and Management Research(IJEMR), 7(3), 62-65 